\title{
New halo- and thermotolerant fermenting bacteria producing surface-active compounds
}

\begin{abstract}
Two new strains of fermenting bacteria were isolated from oily sludge under conditions of enhanced salt concentration (approx. $8 \% \mathrm{w} / \mathrm{v}$ ) and temperature $\left(50^{\circ} \mathrm{C}\right)$. They produced considerable amounts of surface-active compounds that were detected by a newly developed quick and easy half-quantitative test of emulsion stabilization, and were quantified by tensiometry. The chemical structure of the surfactant is unknown. The strains grew fast with inexpensive substrates such as sugars and might be of interest for application in microbially improved oil recovery. Morphological, cytological, and physiological characterization allowed affiliation of the two strains to the genus Bacteroides.
\end{abstract}

\section{Introduction}

For the last 20 years, the application of microbes in improved oil recovery has been discussed as an economical alternative to chemical flooding techniques (Bosecker et al. 1991). The microbes to be employed as producers of gases, acids, solvents, emulsifiers, or biosurfactants in situ have to be tolerant to the conditions prevailing in the oil reservoirs, i.e. lack of oxygen, high pressure, increased salinity, and elevated temperature. Thermophilic (for review, see Brock, 1986) or halophilic (Gilmour 1990) bacteria have been investigated thoroughly, but less attention has so far been directed to bacteria that are both thermophilic and halophilic. It was the aim of the present study to enrich and isolate anaerobic bacteria under conditions of enhanced salt concentration and temperature similar to the reservoir

K. Denger · B. Schink $(\bowtie)$

Fakultät für Biologie, Universität Konstanz, Postfach 5560, D-78434 Konstanz, Germany situation, and to elucidate their fermentation patterns. Since rapid growth with inexpensive, easily degradable substrates is suitable for application in improved oil recovery, we chose various sugars as enrichment substrates. In order to stimulate biosurfactant or emulsifier production, we supplemented the enrichment medium with hexadecane.

\section{Materials and methods}

Bacteria were enriched from brown to blackish oily sedimentary residues of a separation tank or of sludge from a refinery near Hannover, Germany.

The mineral salts medium for anaerobic enrichment and further cultivation was bicarbonate-buffered $(50 \mathrm{mM})$, cysteine-reduced $(1 \mathrm{mM})$, and prepared as previously described (Denger and Schink 1992); in addition it contained $\left(1^{-1}\right) 75.0 \mathrm{~g} \mathrm{NaCl}, 4.0 \mathrm{~g} \mathrm{MgCl} \cdot 7 \mathrm{H}_{2} \mathrm{O}$, $0.3 \mathrm{~g} \mathrm{CaCl} \cdot 2 \mathrm{H}_{2} \mathrm{O}$. The $\mathrm{pH}$ was adjusted to $6.7-6.8$. The $25-\mathrm{ml}$ enrichment cultures were supplemented with $50 \mu$ hexadecane. Subcultures were inoculated with oily drops from the surface of the preculture. Unless stated otherwise, cultures were incubated at $50^{\circ} \mathrm{C}$ in test tubes or infusion bottles sealed with butyl rubber septa under $\mathrm{N}_{2} / \mathrm{CO}_{2}(90: 10, \mathrm{v} / \mathrm{v})$ atmosphere. For aerobic cultivation, a phosphate-buffered mineral medium (Weimer and Zeikus 1977) was used, which was supplemented with $50 \mathrm{~g} / \mathrm{l} \mathrm{NaCl}$, vitamins, and trace elements as described above.

Pure cultures were obtained by repeated application of the agar shake dilution method (Pfennig 1978). Purity was checked microscopically and in a complex medium diluted 1:10 (AC-Medium, Difco). Gram typing (Bartholomew 1962; Gregersen 1978) and oxidase and catalase tests (Gerhardt 1984) were performed following standard procedures. Cytochromes were assayed for by redox spectroscopy as previously described (Denger and Schink 1990). The DNA base ratio was determined by HPLC (Tamoaka and Komagata 1984; Mesbah et al. 1989) after isolation of the DNA according to Cashion et al. (1977).

Acetate, propionate and hydrogen were determined by gas chromatography, using a flame-ionization detector for fatty acids (Platen and Schink 1987), and a thermal-conductivity detector for hydrogen (Denger and Schink 1990). Succinate and sugars were quantified by HPLC with an Interaction ORH-801 organic acids column packed with a cation-exchange polymer (Interaction Chemicals, Mountain View, USA) and refractive-index detection (Gallus and Schink 1994). Production of surface-active substances was first checked half-quantitatively following the unmixing process of 
a hexadecane/water emulsion. The simple but reliable test was carried out in $2-\mathrm{ml}$ polyethylene centrifuge vials. A $0.05-\mathrm{ml}$ sample of alkaline phenolred solution $(0.1 \% \mathrm{w} / \mathrm{v}$ in $10 \mathrm{mM} \mathrm{NaOH})$ was added to $0.5 \mathrm{ml}$ culture fluid. The indicator helped to visualize the reaction and additionally served as a $\mathrm{pH}$ indicator. The mixture was overlayed by $0.5 \mathrm{ml}$ hexadecane and shaken vigorously to produce a homogeneous emulsion. Production of emulsion-stabilizing compounds was indicated by floaming and by incomplete unmixing of the emulsion after a settling time of $5 \mathrm{~min}$. The amount of emulsifiers could be evaluated by carrying out this test assay with various dilutions of the original culture fluid, by the quantity of bubbles at the interface, and by the time it took until they burst. Quantitative measurement of the surface tension was performed with an interfacial tensiometer K8 (Krüss, Hamburg, Germany). Kinematic viscosity was measured with an Ubbelohde viscosimeter (Schott, Hofheim, Germany).

\section{Results}

\section{Enrichment and isolation}

Enrichment cultures in anoxic mineral medium with $75 \mathrm{~g} / 1 \mathrm{NaCl}$ and glucose, fructose, xylose, arabinose, or lactose as substrates ( $5 \mathrm{mM}$ each) were inoculated with $5 \%$ of oily sludge and $50 \mu 1$ hexadecane. The cultures were incubated at $50^{\circ} \mathrm{C}$ in the dark. Turbidity developed within 3-4 days and parts of the oily surface were transferred to subcultures. After several transfers, five strains of halo- and thermotolerant fermenting bacteria were isolated by two subsequent agar-dilution series. One strain isolated with fructose was a sporeforming rod, whereas all the other strains were nonmotile, non-spore-forming, thin rods. Three strains produced an emulsion-stabilizing compound, as visualised with the half-quantitative test described. Two of these strains, Glc12 and Fru22 were chosen for further characterization.

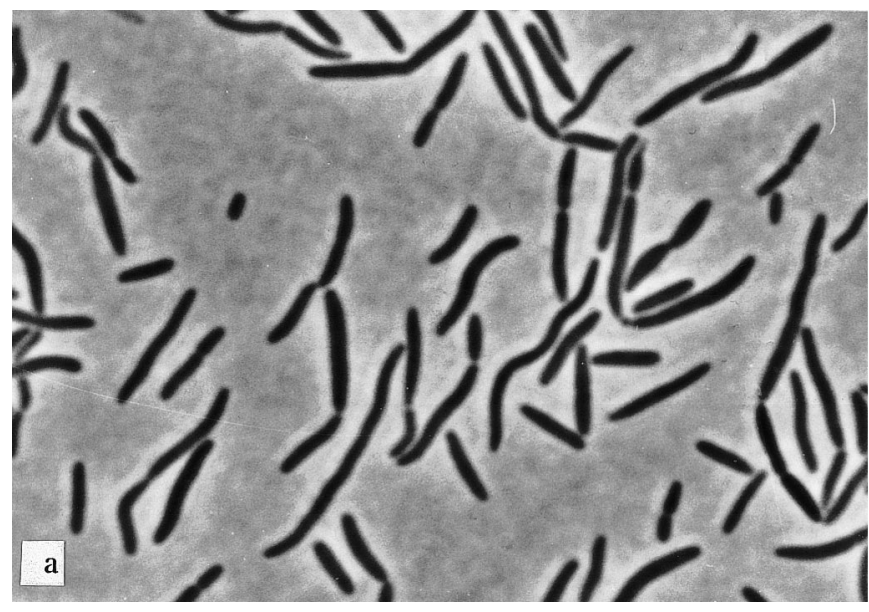

Fig. 1 a,b Phase-contrast photomicrograph of an old culture of strain Glc12 grown with glucose. b Phase-contrast photomicro-
Morphological, cytological, and physiological characterization

Cells of strains Glc12 and Fru22 were gram-negative, non-motile, thin rods that did not form spores (Fig. 1, Table 1). Both strains could grow at $37^{\circ} \mathrm{C}, 50^{\circ} \mathrm{C}$, and $55^{\circ} \mathrm{C}$, but not at $30^{\circ} \mathrm{C}$ and $60^{\circ} \mathrm{C}$. Since salt tolerance was important for possible application of the strains, it was elucidated thoroughly. Both strains could grow

Table 1 Morphological, cytological, and physiological properties of the strains Glc12 and Fru22

\begin{tabular}{|c|c|c|}
\hline Property & Glc12 & Fru22 \\
\hline Cell shape & \multicolumn{2}{|c|}{ Thin irregular rods very thin rods } \\
\hline Cell size $(\mu \mathrm{m})$ & $0.4-0.6 \times 2-10$ & $0.3 \times 3-8$ \\
\hline Motility & - & - \\
\hline Gram type & - & - \\
\hline Spore formation & - & - \\
\hline Cytochromes & $b$-type & $b$-type \\
\hline \multicolumn{3}{|l|}{$G+C$ content of the } \\
\hline DNA $(\mathrm{mol} \%)$ & $42.3 \pm 0.4$ & $41.8 \pm 0.7$ \\
\hline Catalase & - & - \\
\hline Oxidase & - & - \\
\hline \multicolumn{3}{|l|}{ Growth rate } \\
\hline Doubling time (with & 6.5 & 11.6 \\
\hline \multicolumn{3}{|l|}{ Glc/Fru) (h) } \\
\hline \multicolumn{3}{|c|}{ Temperature range: } \\
\hline Growth at $37^{\circ} \mathrm{C}, 50^{\circ} \mathrm{C}, 55^{\circ} \mathrm{C}$ & $\mathrm{C}+$ & + \\
\hline Growth at $30^{\circ} \mathrm{C}, 60^{\circ} \mathrm{C}$ & - & - \\
\hline Salt tolerance $(\mathrm{g} / \mathrm{l} \mathrm{NaCl})$ & $20-120$ & $20-120$ \\
\hline Salt optimum $(\mathrm{g} / \mathrm{l} \mathrm{NaCl})$ & $20-60$ & $20-60$ \\
\hline
\end{tabular}

No growth occurred with 1,150 , and $200 \mathrm{~g} \mathrm{NaCl} / 1$

Aerobic growth

Not used for growth

Lactate, pyruvate, malate, succinate, fumarate, aspartate, methanol, ethanol, ethyleneglycol, acetoin, glycerol

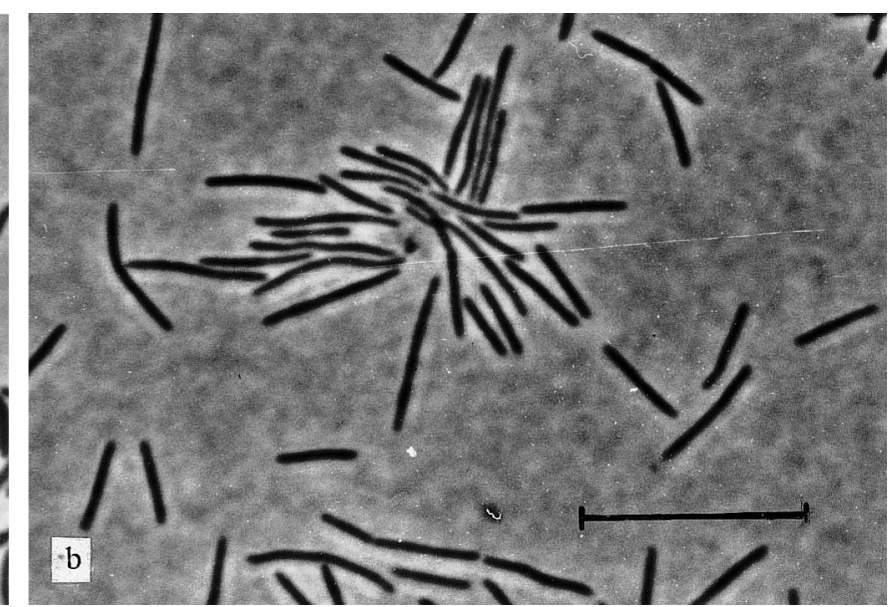

graph of a growing culture of strain Fru22 grown with fructose. Bar $=10 \mu \mathrm{m}$ for both panels 


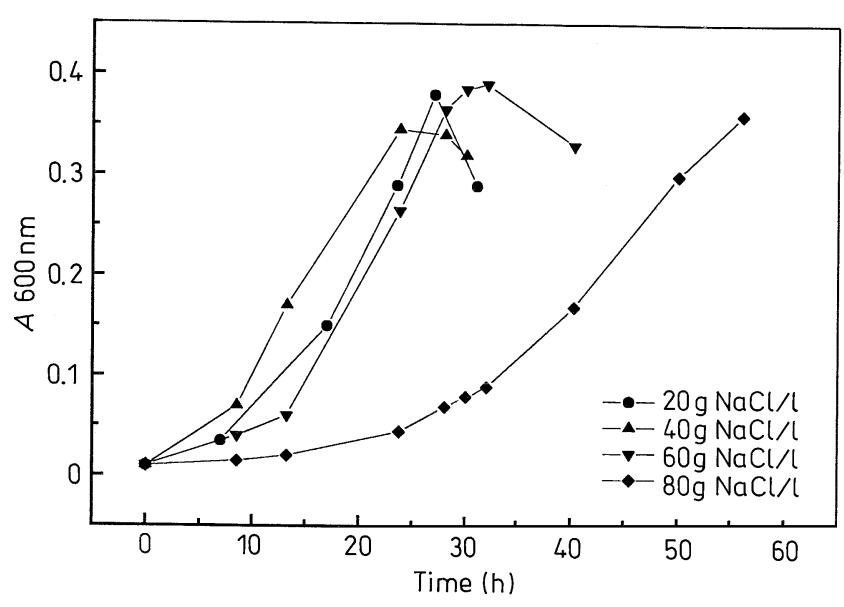

Fig. 2 Growth of strain $\mathrm{Glc} 12$ at various $\mathrm{NaCl}$ concentrations in the medium. Substrate: $4 \mathrm{mM}$ glucose, temperature: $50^{\circ} \mathrm{C}$. Preculture was grown in medium with $75 \mathrm{~g} \mathrm{NaCl} / 1$

with $20-120 \mathrm{~g} \mathrm{NaCl} / 1$ medium. No growth occurred with $1 \mathrm{~g}, 150 \mathrm{~g}$, and $200 \mathrm{~g} \mathrm{NaCl} / 1$ medium. The highest growth rates and growth yields in combination with the shortest lag phases were found in medium with $20-60 \mathrm{~g}$ $\mathrm{NaCl} / 1$, indicating that the salt optimum was within this range (Fig. 2).

Redox difference spectra of membrane fractions showed absorption maxima at $570 \mathrm{~nm}, 539 \mathrm{~nm}$, and $429 \mathrm{~nm}$, as typical of membrane-bound $b$-type cytochromes (Kamen and Horio 1970). The guanineplus-cytosine content of the DNA was $42.3 \pm 0.4$ mol $\%$ for strain Glc12, and $41.8 \pm 0.7 \mathrm{~mol} \%$ for strain Fru22 respectively.

The metabolism of both strains was exclusively fermentative. Neither molecular oxygen, nor nitrate, sulfate, thiosulfate, sulfite, sulfur, or fumarate could be

Table 2 Fermentation stoichiometries and growth yields of strains Fru22 and Glc12. Experiments were carried out in sealed $17-\mathrm{ml}$ Hungate tubes filled with $10 \mathrm{ml}$ medium under $\mathrm{N}_{2} / \mathrm{CO}_{2}(90 \% / 10 \%)$ gas mixture. Strain Fru22 did not grow with lactose, strain Glc12 did not grow with fructose. The cell dry mass was calculated via cell turbidity using the conversion factors $0.1 A_{600}=40.1 \mathrm{mg}$ dry mass $/ 1$ (Glc12), and $0.1 A_{600}=47.4 \mathrm{mg}$ dry mass/liter (Fru22), which were obtained by direct gravimetric determination in 500-ml cultures.

\begin{tabular}{|c|c|c|c|c|c|c|c|c|c|c|}
\hline Strain & Substrate & $\begin{array}{l}\text { Substrate } \\
\text { degraded } \\
(\mathrm{mM})\end{array}$ & $\begin{array}{l}\text { Cell dry } \\
\text { mass } \\
\text { formed } \\
(\mathrm{mg})\end{array}$ & $\begin{array}{l}\text { Substrate } \\
\text { assimilated } \\
(\mathrm{mM})\end{array}$ & $\begin{array}{l}\text { Acetate } \\
\text { formed } \\
(\mathrm{mM})\end{array}$ & $\begin{array}{l}\text { Propionate } \\
\text { formed } \\
(\mathrm{mM})\end{array}$ & $\begin{array}{l}\text { Succinate } \\
\text { formed } \\
(\mathrm{mM})\end{array}$ & $\begin{array}{l}\text { Hydrogen } \\
\text { formed } \\
(\mathrm{mM})\end{array}$ & $\begin{array}{l}\text { Electron } \\
\text { recovery } \\
(\%)\end{array}$ & $\begin{array}{l}\text { Molar } \\
\text { growth yield } \\
(\mathrm{g} / \mathrm{mol})\end{array}$ \\
\hline \multirow[t]{4}{*}{ Fru22 } & Glucose & 5.0 & 1.90 & 1.30 & 1.60 & 3.60 & 1.60 & 0.3 & 97.0 & 38.0 \\
\hline & Fructose & 4.4 & 1.75 & 1.19 & 1.30 & 2.84 & 1.66 & 0.4 & 96.3 & 39.9 \\
\hline & Xylose & 5.0 & 1.61 & 1.34 & 1.16 & 3.60 & 1.20 & 0.4 & 105.6 & 32.2 \\
\hline & Arabinose & 5.0 & 1.53 & 1.30 & 1.40 & 3.30 & 1.30 & 0.3 & 103.0 & 31.2 \\
\hline \multirow[t]{4}{*}{ Glc12 } & Glucose & 5.0 & 1.96 & 1.35 & 1.50 & 2.80 & 2.40 & 0.3 & 97.5 & 39.2 \\
\hline & Xylose & 4.8 & 1.48 & 1.23 & 1.20 & 2.30 & 1.70 & 0.3 & 92.7 & 30.8 \\
\hline & Arabinose & 4.8 & 1.32 & 1.10 & 1.30 & 2.40 & 1.70 & 0.2 & 92.2 & 27.5 \\
\hline & Lactose & 2.5 & 2.00 & 0.68 & 1.70 & 3.30 & 1.90 & 0.5 & 100.0 & 80.0 \\
\hline
\end{tabular}

used as electron acceptors. Except for several sugars, no other substrates, such as dicarboxylic acids, alcohols, lactate, or pyruvate, were degraded (Table 1). Both strains fermented sugars to acetate, propionate, succinate, and small amounts of hydrogen. Strain Glc12 was not capable of degrading fructose, and strain Fru22 did not use lactose as substrate (Table 2). A typical growth curve of strain Glc12 with concomitant product formation is shown in Fig. 3. Both strains grew comparably fast, with doubling times of about $10 \mathrm{~h}$.

\section{Production of surface-active compounds}

To check for production of surfactants in the time course of hexose fermentation, samples were taken at different growth phases as indicated by arrows in Fig. 3, and assayed by the half-quantitative emulsion test and by tensiometry. Growth medium or growth medium supplemented with fermentation products served as controls. Results obtained with both strains are presented in Table 3 (samples 1-12). Surface-active compounds were produced at the end of the exponential growth phase, and production continued while lysis of the cells was underway. Samples 13 and 14 were taken after five growth passages in medium supplemented with hexadecane. The last transfer was carried out into medium without hexadecane to avoid interference of hexadecane with the test. The surface tension was lowered by $8.3 \mathrm{mN} \mathrm{m}^{-1}$ or $11.1 \mathrm{mN} \mathrm{m}^{-1}$ respectively, indicating a stimulating effect of hexadecane supplementation. To investigate whether growth with higher substrate concentrations led to higher production of surface-active compounds, $10 \mathrm{mM}$ of sugar substrate was used instead of the $5 \mathrm{mM}$ solution used for physiological investigations. The surface tension of the

Assimilation of substrates into cell material was calculated using the formula $\left\langle\mathrm{C}_{4} \mathrm{H}_{7} \mathrm{O}_{3}\right\rangle$ for cell material, and the following assimilation equation: $17 \mathrm{C}_{6} \mathrm{H}_{12} \mathrm{O}_{6} \rightarrow 24\left\langle\mathrm{C}_{4} \mathrm{H}_{7} \mathrm{O}_{3}\right\rangle+6 \mathrm{CO}_{2}+18 \mathrm{H}_{2} \mathrm{O}$; $17 \mathrm{C}_{5} \mathrm{H}_{10} \mathrm{O}_{5} \rightarrow 20\left\langle\mathrm{C}_{4} \mathrm{H}_{7} \mathrm{O}_{3}\right\rangle+5 \mathrm{CO}_{2}+15 \mathrm{H}_{2} \mathrm{O} ; 17 \mathrm{C}_{12} \mathrm{H}_{24} \mathrm{O}_{12}+$ $12 \mathrm{H}^{+} \rightarrow 48\left\langle\mathrm{C}_{4} \mathrm{H}_{7} \mathrm{O}_{3}\right\rangle+6 \mathrm{CO}_{2}+36 \mathrm{H}_{2} \mathrm{O}+12 \mathrm{OH}^{-} ;$thus 6.9 $\mu \mathrm{mol}$ hexose, $8.3 \mu \mathrm{mol}$ pentose, or $3.4 \mu \mathrm{mol}$ lactose was degraded to form $1 \mathrm{mg}$ cell material 


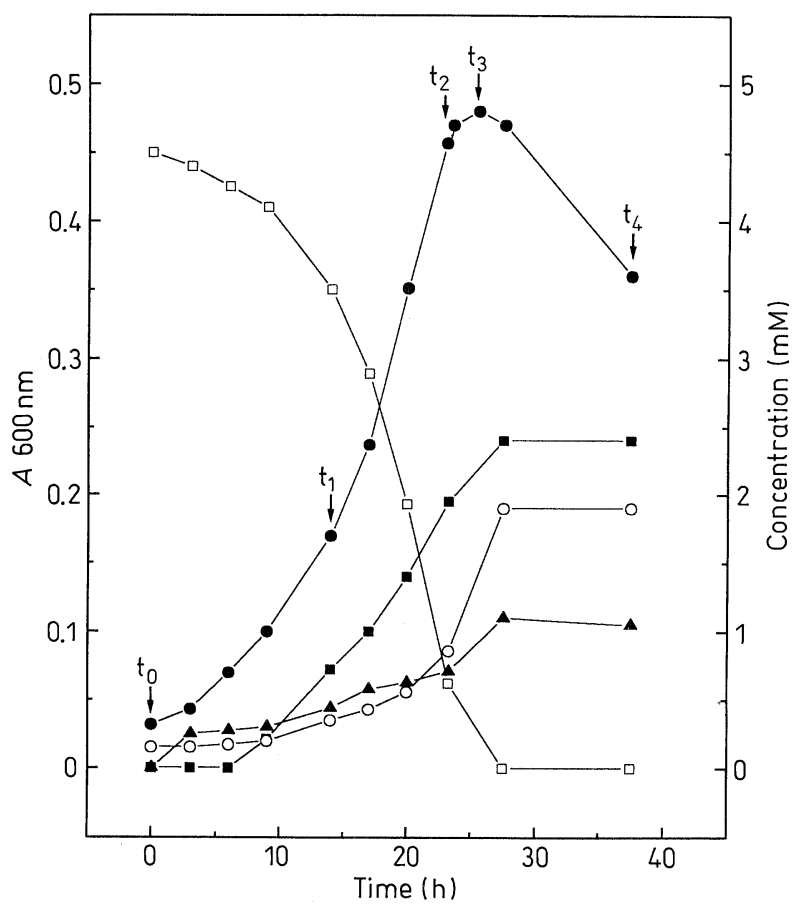

Fig. 3 Time course of glucose fermentation with strain Glc12. Arrows times of sampling. $-A_{600}, \square$ glucose, $\square$ propionate, $\bigcirc$ succinate, $\boldsymbol{\Delta}$ acetate

culture fluid was lowered to $40.3 \mathrm{mN} \mathrm{m}^{-1}$ and 42.3 $\mathrm{mN} \mathrm{m}^{-1}$ for strains Glc12 and Fru22 respectively.

In samples with the highest difference in surface tension (samples 15-18), the kinematic viscosity was also measured. No difference in viscosity was found in comparison to the controls (data not shown).

\section{Discussion}

Enrichment, isolation, and physiology

Five strains of fermenting bacteria were enriched and isolated from oily sludge under conditions of enhanced salt concentration (approx. $8 \% \mathrm{w} / \mathrm{v}$ ) and temperature $\left(50^{\circ} \mathrm{C}\right)$. Since it was the aim of this study to isolate bacteria that produce emulsifiers or biosurfactants, the enrichment medium was supplemented with hexadecane, and the oily drops from the surface of the preculture were transferred to the subculture. Three of the isolated strains produced an emulsion-stabilizing compound, so the applied enrichment conditions seemed to be appropriate to obtain strains capable of producing emulsion-stabilizing compounds. Apparently, production of emulsifiers was stimulated by addition of hexadecane.

The comparably fast-growing new isolates fermented several sugars to acetate, propionate, succinate, and small amounts of hydrogen. As shown by a typical growth curve of stain Glc12 in Fig 3, the absorbance decreased rapidly after substrate consumption, probably as a consequence of lysis of the cells due to the high salt content of the medium.

Hexoses and pentoses were fermented to acetate, propionate, and succinate in about equal molar ratios
Table 3 Lowering of surfacetension of cultures in comparison to controls. Surface tension of distilled water, mineral salts medium, or medium supplemented with fermentation products varied between $65.0 \mathrm{mN} \mathrm{m}^{-1}$ and 70.2 $\mathrm{mN} \mathrm{m}^{-1}$, depending on the cleanliness of the reaction vessel. All measurements were performed at $30^{\circ} \mathrm{C}$

\begin{tabular}{|c|c|c|c|c|c|}
\hline \multirow[t]{2}{*}{ Sample } & \multirow[t]{2}{*}{ Description } & \multirow[t]{2}{*}{ Rapid-test } & \multicolumn{2}{|c|}{ Surface-tension $\left(\mathrm{mN} \cdot \mathrm{m}^{-1}\right)$} & \multirow{2}{*}{$\begin{array}{l}\text { Lowering of } \\
\text { surface-tension } \\
\left(\mathrm{mN} \mathrm{m}^{-1}\right)\end{array}$} \\
\hline & & & Reference & Culture & \\
\hline 1 & Control 1:mineral medium & $n-$ & 69.4 & 69.0 & 0.4 \\
\hline 2 & $\begin{array}{l}\text { Control 2:mineral } \\
\text { medium }+ \text { fermentation } \\
\text { products }\end{array}$ & - & 69.0 & 69.0 & 0.0 \\
\hline 3 & Glc12 growth curve $t_{0}$ & - & 67.5 & 66.8 & 0.7 \\
\hline 4 & Glc12 growth curve $t_{1}$ & - & 68.2 & 65.7 & 2.5 \\
\hline 5 & Glc12 growth curve $t_{2}$ & - & 69.0 & 69.0 & 0.0 \\
\hline 6 & Glc12 growth curve $t_{3}$ & - & 69.7 & 68.0 & 1.7 \\
\hline 7 & Glc12 growth curve $t_{4}$ & \pm & 68.3 & 63.3 & 5.0 \\
\hline 8 & Fru 22 growth curve $t_{0}^{t}$ & - & 67.2 & 67.0 & 0.2 \\
\hline 9 & Fru22 growth curve $t_{1}$ & - & 70.0 & 66.8 & 3.2 \\
\hline 10 & Fru22 growth curve $t_{2}$ & - & 68.0 & 62.9 & 5.1 \\
\hline 11 & Fru 22 growth curve $t_{3}$ & \pm & 67.1 & 62.5 & 4.6 \\
\hline 12 & Fru22 growth curve $t_{4}$ & + & 69.0 & 62.0 & 7.0 \\
\hline 13 & $\begin{array}{l}\text { Glc12, } 5 \text { passages with } \\
\text { hexadecane, } 1 \text { without }\end{array}$ & + & 70.2 & 61.9 & 8.3 \\
\hline 14 & $\begin{array}{l}\text { Fru22, } 5 \text { passages with } \\
\text { hexadecane, } 1 \text { without }\end{array}$ & + & 67.3 & 56.2 & 11.1 \\
\hline 15 & Glc12 10 mM Glc & ++ & 69.0 & 40.3 & 28.7 \\
\hline 16 & $\begin{array}{l}\text { Glc12 } 10 \mathrm{mM} \text { Glc, } \\
\text { filter-sterilized }\end{array}$ & ++ & 67.9 & 49.8 & 18.1 \\
\hline 17 & Fru22 $10 \mathrm{mM}$ Fru & ++ & 68.2 & 42.3 & 25.9 \\
\hline 18 & $\begin{array}{l}\text { Fru22 } 10 \mathrm{mM} \text { Fru, } \\
\text { filter-sterilized }\end{array}$ & ++ & 65.0 & 44.3 & 20.7 \\
\hline
\end{tabular}


(Table 2), approximately according to the following fermentation equations:

$$
\begin{gathered}
3 \mathrm{C}_{6} \mathrm{H}_{12} \mathrm{O}_{6} \rightarrow 2 \mathrm{C}_{2} \mathrm{H}_{3} \mathrm{O}_{2}^{-}+2 \mathrm{C}_{3} \mathrm{H}_{5} \mathrm{O}_{2}^{-} \\
+2 \mathrm{C}_{4} \mathrm{H}^{4} \mathrm{O}_{4}^{2-}+8 \mathrm{H}^{+}+2 \mathrm{H}_{2} \mathrm{O} \\
\Delta G_{0}^{\prime}=-294.4 \mathrm{~kJ} / \mathrm{mol} \text { hexose } \\
9 \mathrm{C}_{5} \mathrm{H}_{10} \mathrm{O}_{5} \rightarrow 5 \mathrm{C}_{2} \mathrm{H}_{3} \mathrm{O}_{2}^{-}+5 \mathrm{C}_{3} \mathrm{H}_{5} \mathrm{O}_{2}^{-} \\
+5 \mathrm{C}_{4} \mathrm{H}_{4} \mathrm{O}_{4}^{2-}+20 \mathrm{H}^{+}+5 \mathrm{H}_{2} \mathrm{O} \\
\Delta G_{0}^{\prime}=-252.4 \mathrm{~kJ} / \mathrm{mol} \text { pentose }
\end{gathered}
$$

Obviously, no $\mathrm{CO}_{2}$ is produced in this unusual type of mixed acid fermentation. The free-energy changes of these reactions (calculated after Thauer et al. 1977) allow synthesis of $4 \mathrm{~mol} \mathrm{ATP} / \mathrm{mol}$ hexose and $3 \mathrm{~mol}$ $\mathrm{ATP} / \mathrm{mol}$ pentose if $70-80 \mathrm{~kJ}$ is assumed to be necessary for irreversible synthesis of 1 mol ATP (Thauer et al. 1977). This correlates with molar growth yields of $40 \mathrm{~g}$ cell matter $/ \mathrm{mol}$ hexose and $30 \mathrm{~g} / \mathrm{mol}$ pentose (Stouthamer 1979), which were determined with our isolates, and with the presence of cytochrome- $b$-dependent electron-transport phosphorylation in fumarate reduction (Schink 1990): Thus, 3.5 ATP rather than 2.7 ATP can be synthesized per hexose residue.

\section{Production of surface-active compounds}

In the present study, we isolated new strains of fermenting bacteria, which produce considerable amounts of emulsion-stabilizing compounds under anoxic conditions. The surface tension of the culture fluid after growth with $10 \mathrm{mM}$ sugar substrate was lowered to $40.3 \mathrm{mN} \mathrm{m}^{-1}$ and $42.3 \mathrm{mN} \mathrm{m}^{-1}$ for strain Glc12 and strain Fru22 respectively, which is considerably high for anaerobes. An effective aerobically produced surfactant can lower the surface tension from $72 \mathrm{mN} \mathrm{m}^{-1}$ to about $30 \mathrm{mN} \mathrm{m}^{-1}$ (Cooper and Zajic 1980), whereas the surface-active substance produced during anaerobic growth of Clostridium pasteurianum only led to a decreased surface tension of $55 \mathrm{mN} \mathrm{m}^{-1}$ (Cooper et al. 1980). The surfactant production with our strains might even increase with higher substrate concentrations.

After growth with $10 \mathrm{mM}$ hexose, cultures were passed through a $0.2-\mu \mathrm{m}$ filter before analysis to investigate whether the activity was bound to the cells or was dissolved in the medium. After passage through the sterile filter, about two-thirds of the activity remained in the medium indicating that the surfactant was released into the medium. The results obtained by tensiometric measurement of surface-active compounds are in complete accordance with the results of the rapid half-quantitative test for emulsifiers. This easy and reliable method might be useful in screening series for strains producing surface-active substances.

\section{Taxonomy}

Gram-negative, anaerobic, non-spore-forming rods are assigned to group 6 according to Bergey's manual of determinative bacteriology (Holt et al. 1994). The fermentation patterns and the guanine-plus-cytosine content of the DNA allow affiliation of the two strains with the genus Bacteroides. The new isolates cannot be assigned to one of the recently created new genera of moderately halophilic bacteria Haloanaerobium (Zeikus et al. 1983), Halobacteroides (Oren et al. 1984), or Sporohalobacter (Oren et al. 1987) because they form different fermentation products and have a higher guanine-plus-cytosine content of the DNA. Assignment to Sporohalobacter is not possible either because our strains do not form spores. Affiliation to a species of Bacteroides would require more detailed studies, e.g. on substrate utilization.

So far, no Bacteroides species is known to be both halo- and thermotolerant, as are our new isolates. The two strains fulfill many demands for microbially improved oil recovery application, e.g. fast anaerobic growth to high densities and production of considerable amounts of surface-active compounds. Moreover, lack of production of gaseous fermentation products, including $\mathrm{CO}_{2}$, allows one to assume that the fermentation product pattern will not be changed at the increased hydrostatic pressures typical of oil reservoirs. The nature of the surface-active compounds is of special interest because no surface-active substances from strictly anaerobic bacteria produced under conditions of enhanced salt concentration $(75 \mathrm{~g} / 1$ medium) and temperature $\left(50^{\circ} \mathrm{C}\right)$ have been described so far (Bosecker 1991).

Acknowledgements We thank Karsten Fischer and Prof. Dr. R. Näveke, TU Braunschweig, for access to their research facilities to measure surface tension and viscosity. This study was financed by Deutsche Wissenschaftliche Gesellschaft für Erdöl, Erdgas und Kohle, and by Bundesministerium für Forschung und Technologie, Bonn, Germany, through the research program "Microbial improved oil recovery" (MIOR).

\section{References}

Bartholomew JW (1962) Variables influencing results and the precise definition of steps in gram staining as a means of standardizing the result obtained. Stain Technol 37:139-155

Bosecker K, Fredrickson H, Hoffmann GG, Kessel D, Näveke R, Schink B, Siemianowski K, Timmis KN, Widdel F, Zabka S (1991) Möglichkeiten einer mikrobiell verbesserten Erdölförderung, DGMK-Forschungsbericht 441-1. Deutsche Wissenschaftliche Gesellschaft für Erdöl, Erdgas und Kohle e.V., Hamburg, Germany

Brock TD (1986) Thermophiles, Wiley New York

Cashion P, Hoder-Franklin MA, McCully J, Franklin M (1977) A rapid method for the base ratio determination of bacterial DNA. Anal Biochem 81:461-466

Cooper DG, Zajic JE (1980) Surface-active compounds from microorganisms. Adv Appl Microbiol 26:229-253 
Cooper DG, Zajic JE, Gerson DF, Manninen KI (1980) Isolation and identification of biosurfactants produced during anaerobic growth of Clostridium pasteurianum. J Ferment Technol $58: 83-86$

Denger K, Schink B (1990) New motile anaerobic bacteria growing by succinate decarboxylation to propionate. Arch Microbiol 154:550-555

Denger K, Schink B (1992) Energy conservation by succinate decarboxylation in Veillonella parvula. J Gen Microbiol 138:967-971

Gallus C, Schink B (1994) Anaerobic degradation of pimelate by newly isolated denitrifying bacteria. Microbiology 140:409-416

Gerhardt P (1984) Manual of methods of general bacteriology. American Society for Microbiology, Washington, DC, pp $413-420$

Gilmour D (1990) Halotolerant and halophilic microorganisms. In: Edwards C (ed) Microbiology of extreme environmemts. McGraw-Hill, New York, pp 147-177

Gregerson T (1978) Rapid method for distinction of gram-negative from gram-positive bacteria. Eur J Appl Microbiol Biotechnol $5: 123-127$

Holt JG, Krieg N-R, Sneath PHA, Staley JT, Williams ST (1994) Bergey's manual of determinative bacteriology, 9th edn, Williams and Wilkins, Baltimore, pp 291

Kamen MD, Horio T (1970) Bacterial cytochromes. I. Structural aspects. Annu Rev Biochem 39:673-700

Mesbah M, Premachandran U, Whitman W (1989) Precise measurement of the $\mathrm{G}+\mathrm{C}$ content of deoxyribonucleic acid by high performance liquid chromatography. Int J Syst Bacteriol 39: $159-167$
Oren A, Weisburg WG, Kessel M, Woese CR (1984) Halobacteroides halobius gen. nov., sp. nov., a moderately halophilic anaerobic bacterium from the bottom sediments of the dead sea. Syst Appl Microbiol 5:58-70

Oren A, Pohla H, Stackebrandt E (1987) Transfer of Clostridium lortetii to a new genus Sporohalobacter gen. nov. as Sporohalobacter lorentii comb. nov., and description of Sporohalobacter marismortui sp. nov. Sys Appl Microbiol 9:239-246

Pfennig N (1978) Rhodocyclus purpureus gen. nov. sp. nov., a ring-shaped, vitamin $\mathrm{B}_{12}$-requiring member of the family Rhodospirillaceae. Int J Syst Bacteriol 28:283-288

Platen H, Schink B (1987) Methanogenic degradation of acetone by an enrichment culture. Arch Microbiol 149:136-141

Schink B (1990) Conversion of small amounts of energy in fermenting bacteria. In: Finn RK, Präve P (eds) Biotechnology, vol 2. Hanser, München, pp 63-89

Stouthamer AH (1979) The search for correlation between theoretical and experimental growth yields. In: Quale JR (ed) Microbial biochemistry, vol 21, pp 1-47, University Press, Baltimore

Tamoaka J, komagata K (1984) Determination of DNA base composition by reversed-phase high-performance liquid chromatography. FEMS Microbiol Lett 25:125-128

Thauer RK, Jungermann K, Decker K (1977) Energy conservation of chemotrophic anaerobic bacteria. Bacteriol Rev 41:100-180

Zeikus JG, Hegge PW, Thompson TE, Phelps TJ, Langworthy TA (1983) Isolation and description of Haloanaerobium praevalens gen. nov. and sp. nov., an obligately anaerobic halophile common to great lake sediments. Curr Microbiol 9: 225-234 